\title{
Super bone scan: bone metastases of prostate cancer
}

\author{
Kiyoshi Shikino, Masatomi Ikusaka, Yusuke Hirota, Eri Sato
}

Department of General Medicine, Chiba University Hospital, Chiba, Japan

\section{Correspondence to}

Dr Kiyoshi Shikino, kshikino@gmail.com

Accepted 31 August 2014
CrossMark

To cite: Shikino $\mathrm{K}$ Ikusaka M, Hirota Y, et al. BMJ Case Rep Published online: [please include Day Month Year] doi:10.1136/ bcr-2014-206886

\section{DESCRIPTION}

A 75 -year-old man presented with a 2-month history of worsening chest and back pain. Physical examination revealed generalised bone tenderness with associated indirect pain; digital rectal examination indicated asymmetric prostatic induration. Laboratory examination revealed high serum alkaline phosphatase (1348 U/L (bone type, 73.2\%)), high $C$ reactive protein $(4.5 \mathrm{mg} / \mathrm{dL})$, high serum ferritin $(2952 \mathrm{ng} / \mathrm{mL})$ and high prostate-specific antigen $\quad(1346 \mathrm{ng} / \mathrm{mL})$. A whole-body technetium-99m methyldiphosphonate (Tc-99m MDP) scan revealed increase in bone uptake with diminished soft tissue activity, faint kidney visualisation and bladder activity; a diagnosis of 'super bone scan' was made (figure 1). Prostate biopsy revealed adenocarcinoma. The diagnosis was bone

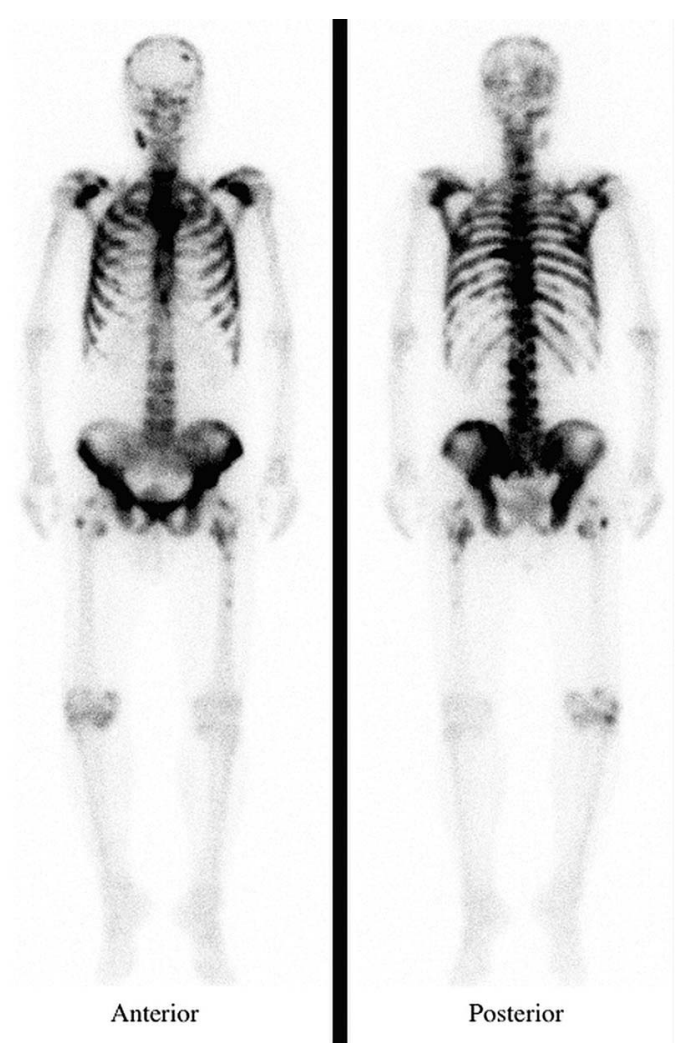

Figure 1 A whole-body technetium-99m methyldiphosphonate scan revealing extremely high bone uptake relative to soft tissue with absent renal radioactivity visualisation. metastases from prostate cancer. Antiandrogens and $\mathrm{GnRH}$ antagonists were administered. At the 3-month follow-up, the pain, alkaline phosphatase, serum ferritin and prostate-specific antigen had improved.

Super bone scan is a special condition of extremely high bone uptake relative to soft tissue with absent renal radioactivity visualisation ('absent kidney sign'). ${ }^{1}$ About $40-60 \%$ of the injected Tc-99m MDP is excreted in the urine. ${ }^{2}$ Therefore, significant renal and bladder radioactivity are normal in most scans. A super bone scan may result from a widespread skeletal process in which there is increased deposition of the bone agent in sites of metabolically active bone. Super bone scans have been described in relation to several conditions such as metastatic disease (prostate/breast cancer), metabolic bone disease (Paget disease/hyperparathyroidism) and myeloproliferative disorders. ${ }^{2}$

\section{Learning points}

- Super bone scan is a special condition of extremely high bone uptake relative to soft tissue with absent or faint renal radioactivity visualisation.

- In any normal bone scan, one expects to see the kidneys and bladder secondary to normal renal excretion of the tracer.

- Super bone scan implicates diffuse metastatic disease, metabolic bone disease and myeloproliferative disorders.

Contributors All authors were involved in the management of the patient. KS wrote the first draft. MI edited the manuscript.

Competing interests None.

Patient consent Obtained.

Provenance and peer review Not commissioned; externally peer reviewed.

\section{REFERENCES}

1 Osmond JD III, Pendergrass HP, Potsaid MS. Accuracy of 99mTC-diphosphonate bone scans and roentgenograms in the detection of prostate, breast and lung carcinoma metastases. Am J Roentgenol Radium Ther Nucl Med 1975;125:972-7.

2 Buckley O, O'Keeffe S, Geoghegan T, et al. 99mTc bone scintigraphy superscans: a review. Nucl Med Commun 2007;28:521-7. 
Copyright 2014 BMJ Publishing Group. All rights reserved. For permission to reuse any of this content visit http://group.bmj.com/group/rights-licensing/permissions.

BMJ Case Report Fellows may re-use this article for personal use and teaching without any further permission.

Become a Fellow of BMJ Case Reports today and you can:

- Submit as many cases as you like

- Enjoy fast sympathetic peer review and rapid publication of accepted articles

- Access all the published articles

- Re-use any of the published material for personal use and teaching without further permission

For information on Institutional Fellowships contact consortiasales@bmjgroup.com

Visit casereports.bmj.com for more articles like this and to become a Fellow 